\title{
Notes
}

\section{A High Elevation Record of the Star-nosed Mole (Condylura cristata) in Northeastern Vermont}

\author{
Ryan W. NORRIS and C. WiLliam KILPATRICK \\ Department of Biology, University of Vermont, Burlington, Vermont 05405 USA; \\ e-mail: rnorris@zoo.uvm.edu and wkilpatr@zoo.uvm.edu
}

Norris, Ryan W., and C. William Kilpatrick. 2007. A high elevation record of the Star-nosed Mole (Condylura cristata) in northeastern Vermont. Canadian Field-Naturalist 121(2): 206-207.

A single male Star-nosed Mole, Condylura cristata, was captured in a rock pile at the top of East Mountain (elevation 1042 $\mathrm{m} ; 3240 \mathrm{ft}$ ) in northeastern Vermont. Although known from high elevations (up to $1676 \mathrm{~m} ; 5500 \mathrm{ft}$ ) in southern U.S. states, this species was not known to occur above $573 \mathrm{~m}(1880 \mathrm{ft})$ in the northern part of its range. This record is also important in confirming that $C$. cristata has some climbing ability when travelling above ground.

Key Words: Star-nosed Mole, Condylura cristata, elevation, talus, Vermont.

The Star-nosed Mole, Condylura cristata, has the largest and most northerly geographic range of all North American moles (Peterson 1966; Hall 1981). The species ranges from southwest Manitoba to Labrador and Nova Scotia, down the eastern United States to South Carolina, and to the Great Lakes region (Petersen and Yates 1980). The species is known to be associated with moist soils near marshes and streams and is an excellent swimmer (Hamilton 1931; Petersen and Yates 1980). Habitat preference for the Star-nosed Mole is usually characterized as low wet ground near bodies of water, swamps, wet meadows, wet spots in fields or low-lying woods, and dry soils within mixed hardwoods near water (Godin 1977; DeGraaf and Yamasaki 2001).

Beane (1995), Laerm et al. (1997), and McCay et al. (1999) have suggested that $C$. cristata is quite common in high elevations in states at the southern edge of its distribution such as North Carolina and South Carolina. Elevational records reported for southern U.S. states include a record at $760 \mathrm{~m}(2494 \mathrm{ft})$ in South Carolina (Laerm et al. 1997) and several individuals from the Smoky Mountain National Park at elevations ranging from 488 to $1676 \mathrm{~m}$ (1600-5500 ft; Linzey and Linzey 1971). Literature records from Canada and northern U.S. states rarely report elevation, but all available records are lower. The highest elevation reported at northern latitudes that we have been able to find is Saunders's (1988) suggestion that $C$. cristata ranges up to $573 \mathrm{~m}(1880 \mathrm{ft})$ in elevation in the Adirondacks of New York.

\section{Study Area and Methods}

The summit of East Mountain in northeastern Vermont was modified in 1955 with the construction of the
North Concord Air Force Station. The ridgeline was levelled creating an area of approximately 17 acres on the summit for this radar station. The rubble from this modification was pushed to the edges, levelling the surface and creating substantial areas of talus. The station was deactivated in 1963; the buildings have slowly deteriorated, and have been partially dismantled. The native fauna and flora have since recolonized the modified area. Dense regenerative sprucefir forest now covers much of the summit and small mammals associated with talus habitat, such as the Yellow-nosed Vole (Microtus chrotorrhinus), have been found in this human-made talus habitat.

During a small mammal survey, 30 Sherman live traps, baited with rolled oats, were set in and adjacent to one of several human-made talus piles at the top of East Mountain (elevation $1042 \mathrm{~m}$ or $3420 \mathrm{ft}$ ), East Haven township, Essex County, Vermont, $44^{\circ} 39.5^{\prime} \mathrm{N}$ $71^{\circ} 46.1^{\prime} \mathrm{W}$ over three nights (23-25 August 2004). Traps were checked daily and rebaited as needed. The talus pile was approximately $20 \mathrm{~m}$ in diameter and contained bare, flattish rocks ranging from $\sim 0.5 \mathrm{~m}$ to $3 \mathrm{~m}$ in diameter. It was located on a gentle slope and had small pools of standing water. No larger streams or bodies of water were observed in the vicinity. Traps in the talus were placed on rocks, not soil, but a small quantity of humus had collected in some areas.

\section{Results}

A single male $C$. cristata was discovered dead in a Sherman trap placed among rocks approximately $5 \mathrm{~m}$ from the edge of the talus pile on the first night of trapping (23 August). This night saw moderate rain with nighttime low temperatures at or approaching $0^{\circ} \mathrm{C}$. The measurements of this specimen are: total 
length $174 \mathrm{~mm}$, tail length $80 \mathrm{~mm}$, and hind foot length $27 \mathrm{~mm}$. Skin, skull, and tissue are housed in the Zadock Thompson Natural History Museum at the University of Vermont (catalog number 5273). Other species captured over the course of these three nights of trapping were Short-tailed Shrew, Blarina brevicauda (1); Smokey Shrew, Sorex fumeus (1), Southern Redbacked Vole, Myodes gapperi (5), and Deer Mouse, Peromyscus maniculatus (8).

\section{Discussion}

The Star-nosed Mole, Condylura cristata, is clearly a more northern-adapted species than other moles in eastern North America. The relatively high number of reports of this species in mountainous areas in southern states is not surprising considering its distribution as far north as Labrador. Our capture of the species at a high elevation site in Vermont was unexpected, particularly considering that it was taken in a talus pile and not associated with soil or long-term standing water. The single specimen reported here is evidence that the Star-nosed Mole also occurs at high elevations (at least $1042 \mathrm{~m} ; 3420 \mathrm{ft}$ ) even in the northeastern USA. This capture also suggests that they can live, or travel through, rocky areas away from soil. Peterson (1966) suggested that Star-nosed Moles spend more time above ground than other mole species and, as a result, are occasionally found dead on the surface or captured on the surface with snap or live traps.

The capture of the mole amongst rocks and not on bare soil suggests that it must have been maneuvering within this rock pile. Hickman (1982) reported observing a vertical climb of $60 \mathrm{~cm}$ by a Star-nosed Mole in the corner of a concrete column, and Schmidt (1931) reported a Star-nosed Mole climbing two feet out of a swimming tank. Our capture provides further indication that $C$. cristata is capable of some degree of climbing, a feature not often attributed to fossorially adapted mammals. Hickman (1982) hypothesized that the climbing ability of $C$. cristata may serve to aid in mobility across rocky areas. Our capture is also consistent with this idea.

\section{Acknowledgments}

The authors thank Charles A. Woods for important discussion leading to the preparation of this manuscript. This specimen was collected in association with a small mammal survey funded by the Kingdom Commons Group.

\section{Literature Cited}

Beane, J. C. 1995. New distributional record for the starnosed mole, Condylura cristata (Insectivora: Talpidae), in North Carolina, with comments on its occurrence in the Piedmont Region. Brimleyana 22: 77-86.

DeGraaf, R. M., and M. Yamasaki. 2001. New England Wildlife: Habitat, Natural History, and Distribution. University Press of New England, Hanover, New Hampshire. 482 pages.

Godin, A. J. 1977. Wild Mammals of New England. Johns Hopkins University Press, Baltimore, Maryland. 304 pages.

Hall, E. R. 1981. The mammals of North America. Volume 1. John Wiley and Sons, New York. 600 pages.

Hamilton, W. J., Jr. 1931. Habits of the star-nosed mole, Condylura cristata. Journal of Mammalogy 12: 345-355.

Hickman, G. C. 1982. Climbing ability of the star-nosed mole, Condylura cristata (Talpidae). Säugetierkundliche Mitteilungen 30: 296-297.

Laerm, J., G., Livingston, C. Spencer, and B. Stuart. 1997. Condylura cristata (Insectivora: Talpidae) in the Blue Ridge Province of western South Carolina. Brimleyana 24: 46-49.

Linzey, A. V., and D. W. Linzey. 1971. Mammals of Great Smoky Mountains National Park. University of Tennessee Press, Knoxville. 114 pages.

McCay, T. S., M. J. Komoroski, and W. M. Ford. 1999. Use of an upland pine forest by the star-nosed mole, Condylura cristata. The Journal of the Elisha Mitchell Scientific Society $115:$ 316-318.

Petersen, K. E., and T. L. Yates. 1980. Condylura cristata. Mammalian Species 129: 1-4.

Peterson, R. L. 1966. The mammals of eastern Canada. Oxford University Press, Toronto. 465 pages

Saunders, D. A. 1988. Adirondack Mammals. State University of New York. 216 pages.

Schmidt, F. K. W. 1931. Mammals of Western Clarke County, Wisconsin. Journal of Mammalogy 12: 99-117.

Received 22 February 2006

Accepted 8 February 2008 